\title{
ANALISIS PERAN PEREMPUAN DALAM MENANAMKAN NILAI-NILAI PENDIDIKAN ISLAM TERHADAP ANAK
}

\author{
Rustina
}

\begin{abstract}
All human beings are creatures of the one God. They are equal, regardless of cultural background. Therefore, they receive the same appreciation from God and that must be respected and glorified. Thus, discrimination based on gender, skin color, class, race, ethnicity, religion, and so on has no basis at all in the teachings of Tawhid. Only the level of taqwa to Allah is the measure of the difference. The concepts of biological and sociocultural differences between men and women view that biological differences between the two are considered natural, while social differences are considered cultural. Whatever the background of these differences, it is not a reason to justify each other because women have the same rights as men in all fields, including education, economy, social, culture, even law and defense and state security. Women deserve special rights. Women should have important roles as well as recognition in various aspects of life. Education for women is very important. Educating women is a fundamental and critical necessity, so they can play their role properly and correctly and give contribution as productive members of the society.
\end{abstract}

Keywords: Women's Role, Islamic Educational Values, Children

\section{PENDAHULUAN}

Persoalan yang paling urgen yang tidak dapat diabaikan dalam membangun generasi suatu bangsa adalah persoalan pendidikan. Bagi suatu negara, pendidikan merupakan realisasi kebijaksanaan untuk meningkatkan taraf kesejahteraan yang di cita-citakan. Pendidikan merupakan komponen pokok dalam pembinaan landasan perkembangan sosial budaya. Pendidikan juga sekaligus penegak kemanusiaan yang berperadaban tinggi. Pendidikan tidak bisa lepas dari kehidupan sosial. Artinya, pendidikan untuk kesejahteraan manusia duniaakhirat sehingga perlu diaplikasikan sebab pendidikan memiliki nilai teologi dan sosiologis sekaligus. Dalam beberapa dekade yang lalu, perempuan tidak memiliki tempat dalam mendapat hak-haknya dalam dunia pendidikan. Kini 
dengan berkembangnya isu demokrasi dan gender pada umumnya maka perempuan mulai berkembang dan mendapatkan akses pendidikan. Di Indonesia, sebetulnya pendidikan perempuan sudah dimulai sejak perjuangan R.A. Kartini untuk memperoleh status sebagai pelajar. Persoalan yang paling urgen yang tidak dapat diabaikan dalam membangun generasi suatu bangsa adalah persoalan pendidikan. Bagi suatu negara, pendidikan merupakan realisasi kebijaksanaan untuk meningkatkan taraf kesejahteraan yang di cita-citakan. Pendidikan merupakan komponen pokok dalam pembinaan landasan perkembangan sosial budaya. Pendidikan juga sekaligus penegak kemanusiaan yang berperadaban tinggi. Pendidikan tidak bisa lepas dari kehidupan sosial. Artinya, pendidikan untuk kesejahteraan manusia duniaakhirat sehingga perlu diaplikasikan sebab pendidikan memiliki nilai teologi dan sosiologis sekaligus. Dalam beberapa dekade yang lalu, perempuan tidak memiliki tempat dalam mendapat hak-haknya dalam dunia pendidikan. Kini dengan berkembangnya isu demokrasi dan gender pada umumnya maka perempuan mulai berkembang dan mendapatkan akses pendidikan. Di Indonesia, sebetulnya pendidikan perempuan sudah dimulai sejak perjuangan R.A. Kartini untuk memperoleh status sebagai pelajar.

Perempuan mempunyai peranan penting dalam pendidikan, karena itu perempuan merupakan tempat pertama anak mendapatkan pengaruh dari anggota keluarganya. Dalam suatu keluarga antara suami dan istri, mereka memiliki tugas dan tanggung jawabnya masing-masing baik di dalam maupun di luar rumah. Suami berkewajiban mencari nafkah, sedangkan istri berkewajiban mendidik anak-anaknya, memberikan kasih sayang, menyusui dan mengasuh mereka, serta tugas-tugas lainnya sebagai seorang ibu. Ibu adalah sosok yang sangat penting yang bertanggung jawab penuh terhadap pendidikan anak di dalam keluarga. Oleh sebab itu, ibu mendapat julukan sebagai uтmи al-madrasatul uula yang berarti Ibu merupakan sekolah pertama bagi anak-anaknya sebelum mereka masuk ke lembaga pendidikan formal.

Anak membutuhkan bimbingan serta perhatian yang ekstra dari kedua orangtuanya dalam masa pertumbuhan jasmani dan perkembangan rohani, mereka memerlukan bantuan dan pertolongan orang lain, dia tidak bisa hidup sendiri 
tanpa pertolongan. Pertolongan sejak awal kepadanya adalah bagian dari pendidikan. Ketika orangtuanya memberi pertolongan kepadanya, maka itulah awal pendidikan baginya setelah dia lahir. Pertolongan yang diberikan kepadanya ada dua bentuk pertolongan yaitu: perawatan fisik, kedua pertolongan dalam pembentukan rohani. Pertolongan dalam bentuk fisik adalah memberinya makanan yang bergizi, merawat fisiknya dengan sebaik-baiknya, demikianlah seterusnya, dan selanjutnya memberikan pendidikan jiwanya. Ditinjau dari segi rohani manusia, maka yang terpenting ialah pendidikan terhadap seluruh potensi rohani manusia yang telah diberikan Allah kepadanya. Ada empat potensi rohani manusia: akal, kalbu, nafs, dan roh. Keempat potensi ini perlu dididik agar menjadi Muslim dalam arti sesungguhnya. ${ }^{1}$

Orang tua, khususnya ibu mempunyai peranan yang besar terhadap pendidikan anaknya karena ibu bertugas sebagai pemegang peran utama dalam menginternalisasi nilai-nilai pendidikan Islam pada anak. Peranan sebagai seorang ibu, ia bertugas mendidik anak yang merupakan amanah dari Allah Swt agar anaknya berhasil di masa depan. Berhasil dalam hal ini bukan pada karier, tetapi lebih pada aspek kognitif, afektif, dan perilaku. Salah satu cara yang dapat dilakukan yaitu dengan menerapkan pola asuh orang tua terhadap anak yang tepat dengan cara memberikan pengawasan dan perhatian yang intensif. Kesalahan yang terjadi dapat berakibat buruk bagi masa depan anak, baik dari segi kognitif, afektif dan perilaku. $^{2}$

Peran ibu dalam mendidik anak sangat penting karena ibu mempunyai pengaruh besar bagi pertumbuhan dan perkembangan seorang anak. Namun, saat ini kebanyakan perempuan memilih menjadi perempuan karier yang memiliki kesibukan di luar rumah, sehingga waktu yang mereka miliki lebih banyak tersita untuk bekerja, padahal waktu tersebut seharusnya digunakan untuk mengurus keluarga dengan baik. Perempuan karier harus memiliki kesadaran diri sebagai

\footnotetext{
${ }^{1}$ Haidar Putra Daulay, Pendidikan Islam dalam Perspektif Filsafat (Cet. I; Jakarta: Kencana, 2014), 11-12.

${ }^{2}$ Nurul Hidayah, "Peran Wanita Karir Dalam Pendidikan Islam Di Dusun Mongkrong, Karangjati, Wonosegoro, Boyolali”, http://eprints.iain-surakarta.ac.id/1539/ (28 Oktober 2020)
} 
ibu rumah tangga yang memiliki tanggungjawab besar di rumah, serta berusaha sebisa mungkin meluangkan waktunya untuk mengawasi, memperhatikan, dan mendampingi anak-anaknya di rumah. Kurangnya waktu saat di rumah akan mengganggu tanggung jawab seorang ibu dalam mendidik anak-anaknya

\section{PEMBAHASAN}

\section{Peran Ganda Perempuan}

Berkaitan dengan perkembangan zaman yang semakin modern, kini telah membawa banyak perubahan sosial. Masyarakat sekarang membutuhkan peran perempuan dalam segala aspek, baik dalam bidang ilmu pengetahuan dan teknologi maupun ketersediaan pasar kerja. Sejalan dengan hal tersebut partisipasi angkatan kerja semakin meningkat karena dipengaruhi oleh tuntutan bangsabangsa atas nama masyarakat global bahwa kemajuan suatu bangsa ditentukan oleh bagaimana bangsa tersebut peduli dan memberi akses yang luas bagi perempuan untuk beraktifitas di ranah publik, sehingga tidak hanya berpengaruh pada angkatan kerja laki-laki saja, namun juga pada perempuan. Hal ini menjadikan perubahan tuntutan peran pada perempuan yang akhirnya mendorong kesetaraan gender dan pemberdayaan perempuan. Maka dari itu, peran perempuan tidak lagi berada dalam lingkup keluarga saja tetapi perempuan juga bisa menjalankan dwiperan atau peran ganda dimana menempatkan peran domestik dan peran publik dalam posisi sama-sama penting. Analisis peran perempuan dapat dilakukan dari perspektif posisi mereka dalam berurusan dengan pekerjaan produktif tidak langsung (domestik) dan pekerjaan produktif langsung (publik), dengan penjelasan sebagi berikut:

\section{Peran Domestik}

Peran domestik adalah ruang lingkup kegiatan perempuan yang berhubungan dengan kegiatan di rumah dan kodratnya sebagai perempuan, yaitu hamil, melahirkan, menyusui, serta menjadi ibu yang bertanggung jawab dalam hal pengasuhan anak dan urusan rumah tangga; seperti membersihkan rumah, 
memasak, juga mengurus segala keperluan suami. ${ }^{3}$ Peran domestik ini menempatkan perempuan memainkan peran tradisi yakni menjadi isteri, ibu rumah tangga dan sebagai seorang ibu dimana peran tersebut segala aktivitasnya dilakukan di dalam rumah dan biasanya tidak dimaksudkan untuk memperoleh penghasilan, melainkan untuk melakukan kegiatan kerumahtanggaan. Perananperanan yang dimaksud adalah:

\section{a. Perempuan Sebagai Istri}

Perempuan yang memiliki peran sebagai seorang istri memiliki tanggung jawab atas keamanan rumah tangganya dan keluarga yang ada dalam rumah tangganya. Ibarat dalam sebuah negara perempuan menjabat selaku Menteri Dalam Negeri, yang antara kewajibannya selain bertanggung jawab kepada Kepala Negara, pun beranggung jawab kepada segenap rakyat dan warga negaranya. Maka dari itu kalau seorang istri pandai dan cakap mengendalikan dan/ atau mampu memimpin rumah tangga, nama selaku kehormatan atas dirinya tentu diberikan oleh suaminya, yang selanjutnya oleh pergaulan dalam lingkungan masyarakat. ${ }^{4}$

Perempuan diciptakan Allah Swt untuk mendampingi laki-laki dan menjadi pakaian bagi suaminya begitupun sebaliknya, maksudnya yaitu fungi dari pakaian adalah menutup aurat/ hal yang rawan serta kekurangan-kekurangan. Ini berarti masing-masing memiliki kekurangan yang tidak dapat ditutupi kecuali dengan bantuan lawan jenisnya, maka dari itu perempuan dan laki-laki diciptakan sama-sama saling membutuhkan dan saling melengkapi, perempuan dan laki-laki saling menjaga satu sama lain untuk keharmonisan keluarganya. Begitulah istri yang cantik perangainya akan menjadikan suami yang baik budi pekertinya.

b. Perempuan Sebagai Ibu Rumah Tangga

Dari zaman dahulu sampai sekarang perempuan memiliki peranan yang sangat penting sebagai ibu rumah tangga yang meliputi segala macam pekerjaan ringan maupun berat, seperti membersihkan rumah, mencuci, memasak,

${ }^{3}$ Umaimah Wahid dan Ferrari Lancia,'Pertukaran Peran Domestik dan Publik Menurut Perspektif Wacana Sosial Halliday”, https://doi.org/10.29313/mediator.v11i1.3180 (28 September 2021).

${ }^{4}$ Moenawar Chalil, Nilai Wanita, (Solo: Ramadhani, 1984), 126. 
mengasuh serta mendidik anak, dan sebagainya yang oleh sebagian besar dari perempuan yang memiliki peran sebagai seorang ibu harus dikerjakan sendiri, tanpa bantuan tenaga orang lain sehingga waktunya habis untuk mengurus rumah tangga dan tidak memiliki waktu untuk dirinya sendiri. Ibulah yang paling banyak mengorbankan diri untuk kepentingan keluarga, sehingga Islam menempatkan kewajiban berbuat baik kepada kedua orang tua khususnya kepada ibu pada urutan kedua setelah kewajiban taat kepada Allah, bukan hanya disebabkan ibu memikul beban berat dan pengorbanannya akan tetapi karena ibu juga dibebani tugas menciptakan pemimpin-pemimpin umat dengan memberikan pendidikan kepada anaknya sebagai generasi penerus bangsa.

c. Perempuan Sebagai Pendidik

Perempuan merupakan benteng utama dalam keluarga karena peningkatan Sumber daya manusia dimulai dari peran perempuan dalam mengurus dan mendidik anak-anaknya agar mampu menjadi generasi yang berkualitas, karena peran utama yang diinginkan Islam itu sendiri adalah mengurus rumah tangganya terlebih lagi mengurus dan mendidik anak-anaknya.

d. Perempuan Sebagai Tenaga Medis

Perempuan merupakan makhluk yang pandai merawat diri dan kepandaiannya dalam merawat diri mengalahkan pria. Perempuan sangat sadar bahwa memelihara tubuh merupakan bagian dari perintah Allah yaitu menjaga kebersihan. ${ }^{5}$ Berdasarkan uraian tersebut dapat diartikan bahwasanya perempuan memang benar-benar memiliki peran yang baik sebagai medis dalam keluarganya. Perempuan harus mampu menjadi yang terbaik dalam ruang lingkup keluarganya terutama mengenai kesehatan. Seperti merawat suami, anak-anaknya, orang tuanya, bahkan mertuanya. Merawat mertua itu tidak dilarang bahkan itu perbuatan yang mulia karena mertua telah menjadi ayah/ ibu menantunya.

${ }^{5}$ Iis Nuraeni Afgandi dan Novi Hidayati Afsari, Ternyata Wanita Bukan Makhluk Lemah, (Bandung: Ruang Kata, 2011), 61. 
Rustina, Analisis Peran ... | 209

\section{Peran Publik}

Peran publik adalah ruang lingkup kegiatan perempuan yang dilakukan di luar rumah yang bertujuan untuk mendatangkan penghasilan. Peran-peran di wilayah publik mempunyai karakteristik yang menantang, dinamis, leluasa, independen, diatur dengan jam kerja, prestasi, gaji, jenjang karier, kemudian dikenal dengan peran produksi yaitu suatu proses kerja yang langsung menghasilkan uang. ${ }^{6}$

Peran perempuan tidak hanya di lingkungan domestik semata, tetapi juga terlibat dalam kehidupan umum (publik) karena perempuan merupankan anggota masyarakat yang mana ikut terlibat dalam rangka memajukan masyarakat. Dalam hal ini, tugas pokok perempuan sebagai ibu dan pengatur rumah tangga yang sering disebut sebagai peran domestik tidak berarti membatasi perempuan pada peran pokok itu saja, karena pada saat yang sama, perempuan juga dibutuhkan untuk dapat berperan di sektor publik. ${ }^{7}$ Perempuan yang memilih untuk bekerja di luar rumah harus bisa menyeimbangkan antara mengurus rumah tangganya dengan pekerjaannya di luar rumah. Tidak ada batasan bagi perempuan yang ingin bekerja di luar rumah selama norma-norma agama dan susila tetap terpelihara dengan baik, serta tidak melupakan kewajibannya dalam mengurus rumah tangganya dan mendidik anak-anaknya.

\section{Peran Perempuan sebagai Pendidik}

Perempuan memiliki peranan yang sangat penting dalam hal pendidikan, bahkan pendidikan pertama yang diberikan kepada anak ialah dari seorang ibu. Ibu memiliki andil yang besar dalam melakukan pengembangan potensi anak. ... Ada sebuah pepatah yang mengatakan jika perempuan cerdas akan melahirkan anak-anak yang cerdas pula.

Peranan orang tua bagi pendidikan anak adalah memberikan dasar pendidikan, sikap, dan pentingnya peranan orang tua dalam pendidikan anak telah disadari oleh banyak pihak. Pendidikan dan perempuan, kedua elemen yang 2008), 142

${ }^{6}$ Mufidah Ch, Psikologi Kelurga Islam Berwawasan Gender (Malang: UIN Malang Press,

${ }^{7}$ Siti Muslikhati, Feminisme dan Pemberdayaan Perempuan dalam Timbangan Islam (Jakarta: Gema Insani Press, 2004), 131. 
berbeda namun tak dapat dipisahkan. Sistem pendidikan jika tak menyertakan perempuan maka itu bukan esensi pendidikan, karena pendidikan adalah bagimana menciptakan keadilan yang humanis. Karena dengan mengalienasi perempuan dari pendidikan, maka sama halnya dengan melanggengkan kebodohan untuk dominasi kekuasaan pada segelintir mahkluk.

Salah satu permasalahan yang dianggap paling berat untuk perempuan ialah rekognisi pendidikan untuk perempuan, realitas yang umum kita jumpai perempuan selalu dipandang sebelah mata. Karena pendidikan untuk perempuan tak diterapkan secara fundamental, hanya sebagai formalitas semata atau lebih parahnya jika pandangan bahwa pendidikan untuk perempuan seharusnya tak diberikan sama sekali, agar tunduk pada sistem dan semakin terkungkung dalam penindasan.

Pemikiran akan pentingnya pendidikan untuk perempuan tak hanya dilayangkan oleh para pemikir Barat saja, namun dalam konteks Indonesia, ada pemikir serta pegiat perempuan lokal yang memperjuangkan hak perempuan untuk memperoleh pendidikan secara layak,dia adalah R.A. Kartini. Kartini menuangkan pemikirannya dalam surat-surat yang dikirimkan kepada J. H. Abendanon. Kumpulan surat pribadi Kartini tersebut kemudian diterbitkan pada tahun 1912 dengan judul Door Duisternis Tot Licht (Habis Gelap Terbitlah Terang). Kumpulan surat Kartini tersebut menjadi sebuah alternatif pemikiran tentang pendidikan perempuan. Sebagai sebuah kritik sosial pada realitas, bahwasanya perempuan juga perlu pendidikan. Salah satu pokok substansi pemikiran Kartini adalah Emansipasi atau upaya mewujudkan kesetaraan perempuan dalam mendapatkan Pendidikan. ${ }^{8}$

Kedua pernyataan tersebut dapat digunakan sebagai acuan tentang peran perempuan dalam hal pendidikan, bagaimana institusi pendidikan dan lingkungan memberikan hak kepada perempuan untuk memperoleh pendidikan dengan sepenuhnya tanpa ada intrik sosial. Perempuan jangan lagi mengalami ketertinggalan perihal pemikiran dan pengetahuan. Karena aspek pendidikan untuk perempuan berpengaruh pada segala bidang, bahkan jika seorang perempuan

\footnotetext{
${ }^{8}$ Ibid.
} 
memilih menjadi ibu rumah tangga, diperlukan pula pembekalan akan hal tersebut. Pendidikan bukan hanya milik perempuan yang memiliki akses ekonomi atau strata sosial menengah ke atas, melainkan dapat dinikmati oleh seluruh perempuan secara merata, itulah arti kesetaraan itu sendiri.

\section{Pentingnya Pendidikan Bagi Perempuan}

Perempuan memiliki peranan yang sangat penting dalam hal pendidikan, bahkan pendidikan pertama yang diberikan kepada anak ialah dari seorang ibu. Ibu memiliki andil yang besar dalam melakukan pengembangan potensi anak. Bukan berati tugas mendidik hanya diberikan kepada ibu semata, ayah juga berpengaruh terhadap proses pendidikan anak, namun tidak seotentik seorang ibu. Karena ibu memiliki keterikatan batin yang kuat dengan anak. Ada sebuah pepatah yang mengatakan jika perempuan cerdas akan melahirkan anak-anak yang cerdas pula. Hal tersebut dapat dimaknai bahwa pendidikan akan berpengaruh dalam pola pikir dalam berkeluarga, cara mendidika anak dan menerapkan prinsip-prinsip keadilan di keluarga.

Kartini dapat dikatakan sebagai tokoh pembaru di bidang pendidikan perempuan, yang memiliki terobosan dalam mengajarkan pentingnya arti pendidikan bagi perempuan. Perjuangannya tersebut berhasil memberikan perubahan bagi perempuan menuju pemikiran yang lebih maju. Bahwa semestinya perempuan juga harus memiliki peranan penting dalam lingkungan sosial mereka. Sukarno kemudian menafsirkan perempuan dalam sepenggal kalimat "Perempuan itu tiang negeri, ${ }^{9}$ dalam konteks kalimat dari Sukarno tersebut, maka seharusnya perempuan sadar akan posisinya untuk mencetak peradaban bangsa yang berkemajuan. Sedangkan alat untuk menjalankannya ialah pendidikan, jika perempuan mendapatkan pendidikan yang baik, maka jangan heran jika sebuah negara atau institusi di mana perempuan itu berpijak akan mengangkat martabat bangsa.

\footnotetext{
${ }^{9}$ Chabaud Jacqueline, Mendidik dan Memajukan Wanita, (Jakarta: Gunung Agung Depag RI, 2005), 146 .
} 
Pendidikan bukan hanya berkaitan soal mengasah akal dan tingkat intelektual saja, namun juga memperhatikan kepribadian. Kartini mengatakan jika pendidikan bukan hanya mempertajam akal, budi pekerti pun juga harus dipertinggi. Intinya ialah dalam menjalankan sistem pendidikan, tidak hanya mengutamakan tingkat kecerdasan semata, namun juga menanamkan budi pekerti pula. Jika hanya mengunggulkan sisi kecerdasan tanpa memperhatikan hal yang lain, maka yang terjadi ialah rasa superioritas dan rendahnya sikap kemanusiaan.

Pendidikan diberikan bukan hanya dalam lembaga formal saja, namun juga diperlukan bimbingan pendidikan non formal. Pendidikan formal tidak sepenuhnya berjalan baik jika tidak diiringi oleh pendidikan non formal yang berupa peranan keluarga dan lingkungan dalam penerapan pendidikan. Joesoef Sulaiman dalam Konsep Dasar Pendidikan Luar Sekolah mengemukakan:

"Di dalam keluargalah anak pertama-tama menerima pendidikan, dan pendidikan yang diperoleh dalam keluarga ini merupakan pendidikan yang terpenting atau utama terhadap perkembangan pribadi anak." 10

Keluarga adalah elemen terpenting dalam pembentukan dan pengembangan karakter seorang anak. Itulah sebabnya penekanan pendidikan kerap kali diberikan pada pendidikan non formal atau keluarga. Karena keluarga berperan sebagai pendidik. Hal ini berkaitan pula pada penjelasan tentang peran perempuan untuk memberikan pendidikan pada generasi selanjutnya.

\section{Hambatan Penerapan Pendidikan Pada Perempuan}

Kesadaran terhadap pentingnya pendidikan terhadap perempuan masih tergolong rendah, tak jarang hal tersebut terjadi pada perempuan itu sendiri. Terkadang perempuan masih terjebak pada zona nyaman yang tak jauh dari dunia gemerlap, terdapat faktor internal dan eksternal sehingga menyebabkan pemikiran yang rabun akan dunia pendidikan. Salah satunya ialah faktor ekonomi yang mengharuskan perempuan tak dapat merasakan senangnya hidup dalam dunia pendidikan.

\footnotetext{
${ }^{10}$ Ibid, 20.
} 
Di lain sisi, perempuan masih mengalami tindakan represif yang didasari oleh interpretasi agama yang cenderung dimaknai secara konservatif dan cenderung bias gender. Pemikiran tersebutlah yang menyebabkan terjadinya kemunduran dalam konteks pendidikan bagi perempuan. Salah contohnya ialah kisah Malala Yousafzai yang berjuang untuk mendapatkan pengakuan atas idealismenya, dia memperjuangkan agar perempuan muda di Pakistan mampu mengenyam bangku pendidikan. Karena dalam budaya setempat, perempuan yang berpendidikan ialah monster dan tidak sesuai dengan budaya setempat. Situasi yang sama juga dirasakan perempuan Margdarshi dari India atau perempuan muda sub-Sahara Afrika yang terpaksa berhenti sekolah karena mengalami menstruasi dan terjadinya olokan yang tumbuh karena faktor menstruasi, serta sulitnya menapatkan pembalut yang menyebabkan mereka untuk merelakan pendidikan

Sedangkan di Indonesia sendiri, terdapat faktor ekonomi yang menjadi salah satu faktor ketertinggalan perempuan untuk merasakan pendidikan. Pada Mei 2017 lalu, Sanita gadis yang berasal dari Jawa Tengah yang akan dinikahkan orang tuanya pada usia yang cukup belia yakni 13 tahun, atas dasar kesulitan secara ekonomi. Namun ia menolak dan mengatakan: "Jika Bapak dan Ibu menghentikan pernikahan ini dan membiarkan saya melanjutkan pendidikan, saya akan membayar seluruh biaya yang Bapak dan Ibu habiskan buat saya. Jika Bapak dan Ibu memaksa saya menikah, maka saya tidak akan punya apa-apa lagi,

Alasan lain menyebutkan bahwa adanya intervensi atau campur tangan antara urusan rumah tangga dan pendidikan, ketika perempuan ingin melanjutkan studi yang lebih tinggi. Maka akan ada hambatan yang menjelaskan bahwa pernikahan menjadi urusan utama daripada studi, jika merujuk pada kasus Sanita. Dalam konteks budaya yang umumnya kita jumpai di masyarakat Jawa, ada sebuah ungkapan seperti, lebih baik menikah di usia dini daripada harus menjadi perawan tua karena mementingkan studi, begitu kasarannya.

Padahal jika diteliti, semangat untuk berpendidikan makin lama kian pudar seiring dengan hambatan-hambatan yang terjadi. Jikalau menikah dibarengi dengan studi, maka perempuan akan mengalami peran ganda dan mengharuskan 
perempuan untuk bekerja keras untuk melakukan penyeimbangan, dalam konteks sosial yang masih berlutut pada pemikiran gender konvensional. Seperti pemikiran yang mengungkapkan bahwa suatu hal yang wajar jika laki-laki bekerja atau memperoleh segala impiannya, baik melakukan pengembangan diri ataupun melanjutkan studi, bukan mengurusi perkara domestik.

Di samping itu perempuan juga masih sering terjadi diskriminasi gender pada ruang dan upah kerja. Terlebih lagi hal tersebut terjadi jika berasal dari kelompok minoritas, dalam penelitiannya Settles, dkk menemukan adanya diskriminasi pada perempuan kulit hitam yang mempengaruhi psikis dari perempuan tersebut. Hal ini dapat dilihat dari hasil penemuan Settles, dkk yang mengatakan jika perempuan kulit hitam memiliki intensitas kepuasan kerja lebih minim daripada perempuan kulit putih. Penurunan kepuasan kerja tersebut, dilatarbelakangi oleh diskriminasi yang secara tidak langsung memicu tekanan dalam bekerja.

Perempuan masih mendapat tekanan yang beranggapan bahwa kurangnya tingkat produktivitas daripada laki-laki, sekalipun ia dapat menyangkalnya dengan kinerja yang dia berikan. Sehingga lambat laun akan menyebabkan pemudaran pada tingkat kepercayaan dirinya untuk melakukan berbagai tindakan. Padahal sebetulnya, perempuan berpengaruh besar pada setiap proses kehidupan.

Proses diskriminasi, pelecehan hingga tindakan yang cenderung merisak perempuan, merupakan realitas yang kita jumpai sekarang. Problem dari hambatan pendidikan ialah budaya patriarki yang masih dominan, sehingga turut mempengaruhi corak kebijakan terkait pendidikan. Selain itu terdapat diskriminasi secara budaya, di mana perempuan ditemptkan dalam subsistem di bawah laki-laki, hak-haknya dipinggirkan dan dikesampingkan.

Maka perlu ditekankan jikalau kurang meratanya pendidikan terutama untuk perempuan, tidak hanya diakibatkan oleh faktor ekonomi namun juga ada pengaruh dari budaya. Padahal berpuluh-puluh tahun yang lalu Kartini mengajarkan pentingnya emansipasi terhadap perempuan, minimal melalui pemberian akses pendidikan secara meluas. Namun dalam praktiknya masih belum berjalan maksimal, sehingga perempuan masih terkungkung dalam sangkar emas. 
Pengangkatan tema-tema berkaitan dengan perempuan didalam al-quran menunjukan bahwa al-quran memberi perhatian khusus terhadap perempuan yang pada saat al-quran diturunkan kedudukannya sangat rendah dihadapan kaum lakilaki. Islam mengangkat derajat perempuan setara dengan kaum laki-laki. Namun demikian masih banyak orang yang telah menurunkan derajat dan menjadikan wanita sebagai barang mainan kaum laki-laki. Padahal al-quran telah memposisikan laki-laki dan perempuan secara seimbang, sebagaimana firman Allah: Artinya: "Dan para wanita mempunyai hak yang seimbang dengan kewajibannya menurut cara yang ma'ruf. akan tetapi para suami, mempunyai satu tingkatan kelebihan daripada isterinya dan Allah Maha Perkasa lagi Maha Bijaksana”. (Q.S.Al-Baqarah:228). Jauh sebelum islam datang, perempuan tidak mendapat tempat terhormat dalam kehidupan masyarakat. Pada masa kejayaan bangsa Yunani perempuan dipandang sebagai benda mati yang dapat diperjual belikan di pasaran. Sebagian mereka memandangnya sebagai penyebab persengketaan, peperangan dengan kehancuran dan bahkan lebih dari itu, perempuan dipandang sebagai lambang kekejian dari perbuatan syaithan. Tetapi dengan datangnya Islam di dunia ini membawa perubahan baru terhadap status dan peran perempuan. ${ }^{11}$

Sayyid Amir Ali melukiskan kedudukan perempuan dengan sangat tepat sebagai berikut: Dalam peraturan-peraturan yang diumumkan oleh Rasulullah, Ia dengan keras melarang kebiasaan kawin bersyarat dan meskipun pada mulanya perkawinan sementara diam-diam dibenarkan, pada tahun ketiga Hijriyah itupun dilarang. Dalam sistem agama Rasulullah memberikan kepada perempuan hakhak yang sebelumnya tidak mereka dapatkan. Tadris, Volume 13/ No. 2/ Tahun 2019 | 6 Diberinya mereka kedudukan yang tidak beda sama sekali dengan kaum pria dalam menjalankan segala kekuasaan hukum dan jabatan Maka sejak itu tokoh-tokoh penting perempuan dalam berbagai bidang ilmu pengetahuan terutama dibidang pendidikan Islam. Dengan pemberian kesempatan yang luas dan penghormatan yang tinggi kepada perempuan maka sejak itu muncullah

\footnotetext{
${ }^{11}$ Ali Sayyid Amir, Api Islam, (Terjemahan HB Yasin). (Jakarta: PT. Pembangunan 1967), 97.
} 
tokoh-tokoh penting perempuan dalam berbagai bidang ilmu pengetahuan terutama sekali dibidang pendidikan Islam.

Diantara tokoh-tokoh perempuan tersebut antara lain yaitu: 1. Aisyah $(9 \mathrm{H}-$ 58 H.613 M-678 M), Isteri tercinta dari Nabi Muhammad saw. Wanita cantik yang digelarkan Nabi "Humaira" (pipi yang kemerah-merahan) ini, seorang intelek tinggi orator kaliber besar, yang senantiasa mendampingi suaminya Nabi dalam suka dan duka, melanjutkan tugas suci Khadijah sebelumnya. Ilmu hadits namanya terkenal karena 2210 buah hadits Nabi yang diriwayatkan daripadanya. 2. Fathimah (11 H-18 H.605-632 M), anak puteri Nabi dari istrinya Khadijah. Wanita intelek Quraisy, yang berlidah fasih bicara, menikah dengan pemuda Ali bin Abi Thalib sewaktu umurnya 18 tahun. 3. As-Syifa ${ }^{e e}(20 \mathrm{H}-640 \mathrm{M})$, terkenal dengan “ummu sulaiman”, binti Abdullah bin „Abde Syamsin Al-,,Adawiyah AlQuraisyiyah. Seorang guru ,yang mengajar menulis dan membaca sejak dari zaman sebelum Islam. Ia telah mengajar isteri Nabi, Hafshah binti Umar. Masih banyak perempuan-perempuan Muslim terpelajar lainnya yang menjadi guru, penulis dan sastrawan, dan mendapat penghormatan yang demikian tinggi dari masyarakat Muslim. Ulama-ulama perempuan tersebut senantiasa menjadi figur yang menginspirasi perempuan -perempuan Muslim untuk berusaha mengungguli mereka. Ajaran Al-Qur'an, serta Sejarah mengenai perempuan-perempuan Muslim terkemuka tersebut juga senantiasa menjadi landasan bagi kaum feminis Muslim dalam memperjuangkan pendidikan bagi perempuan. ${ }^{12}$

Di negara -negara yang masyarakatnya adalah masyarakat Muslim seperti negaranegara Arab, kelihatan jelas terjadinya ketimpangan antara laki-laki dan perempuan khususnya dalam bidang pendidikan sebagaimana tergambar dalam data statistik mengenai perempuan di dunia Arab. Di lihat dari jumlahnya, perempuan masih tertinggal dari laki-laki baik dalam tingkat pendidikan dasar maupun tingkat menengah. Di Mesir pada tahun 1990, Tadris, Volume 13/ No. $2 /$ Tahun 2019 | 7 misalnya, terdapat 76 perempuan dalam setiap 100 laki-laki pada tingkat pendidikan menengah. Di Tunisia, perbandingan jumlahnya adalah 77;

${ }^{12}$ Ali, Engineer, Asghar, Hak-Hak Perempuan Dalam Islam, Terj. Farid Wajidi Dan Cicik Farkha, (Yogyakarta: LSPPA, 2000), 45. 
dan di Maroko jumlahnya 69. Ketimpangan ini juga bisa dilihat dalam Pendidikan tingkat dasar: 80 perempuan dalam setiap 100 laki-laki di Mesir, 87 di Syiria, 66 di Maroko. Sedangkan di Saudi Jumlahnya adalah 84. Hal tersebut menjelaskan dengan jujur bahwa semua jumlah tersebut menunjukkan sebuah tanda perbaikan dari apa yang menjadi masalah pada dua puluh tahun sebelumnnya. Meski demikian, perbedaan jumlah antara laki-laki dan perempuan yang bersekolah masih demikian menyolok. ${ }^{13}$ Al-Qur'an, sebagai prinsip-prinsip dasar atau pedoman moral tentang keadilan, mencakup berbagai anjuran untuk menegakkan keadilan teologis (agama), ekonomi, politik, budaya, kultural termasuk keadilan gender. ${ }^{14}$ Secara diskrit, di dunia ini yang diakui sebagai manusia "lumrah" adalah manusia yang berjenis kelamin laki-laki dan perempuan. Meskipun menyandang predikat sebagai manusia "lumrah", akan tetapi terdapat ketimpangan di antara keduanya, represi (penindasan) yang sungguh luar biasa. Laki-laki menguasai perempuan dalam berbagai bidang kehidupan, ini adalah realitas yang tidak bisa ditolak oleh siapapun ${ }^{15}$ Al-Qur'an telah menjaga keseimbangan dalam sejarah yang dituturkannya dengan secara eksplisit menjelaskan bahwa yang membedakan antara laki-laki dan perempuan adalah perbuatan yang mulia (takwa). Tidak kemudian dari jenis kelamin menjadi alasan untuk menindas perempuan dan karena jenis kelamin menjadikan perempuan terhalang untuk memperoleh hak-hak sebagai manusia, perbedaan jenis kelamin tidak lain hanyalah sekedar penanda. Sedangkan dalam pandangan Mazhab Abu Hanifah sebagaimana yang dikutip oleh M. Quraish Shihab, banyak persamaan perempuan dan laki-laki. Mereka sama dalam kemanusiaan, sama dalam asal kejadian, sama dalam hak-hak sipil mereka. Perempuan boleh menjual, membeli, kawin mengawinkan (dirinya) sendiri, menjadi hakim, saksi. Agama Islam menjamin hak-hak perempuan dan memberikan perhatian serta kedudukan

\footnotetext{
${ }^{13}$ Ibid, 71.

${ }^{14}$ Fakih Mansur, Analisis Gender dan Transformasi Sosial (Cet. IX; Yogyakarta: Pustaka Pelajar, 2005), 135.

${ }^{15}$ Hasyim, Pengantar Feminisme dan Fundamentalisme Islam (Cet. I; Yogyakarta: LkiS, 2005), 15.
} 
terhormat pada perempuan yang hal ini tidak pernah dilakukan oleh agama atau syariat sebelumnya. ${ }^{16}$

Sebelum Islam datang, kaum perempuan pernah terpuruk jauh ke dasar yang paling terhina dimana kaum perempuan tidak punya harga diri sama sekali, di perjual belikan, di hadiahkan, dan di permainkan, sehingga orang-orang bangsawan quraisy malu mempunyai anak-anak perempuan yang karenanya di kubur hidup-hidup sebelum orang lain Tadris, Volume 13/ No. 2/ Tahun 2019| 8 tahu. Sedangkan kaum laki-laki menempati posisi sentral dalam masyarakat. Mereka bertanggung jawab secara keseluruhan dalam persoalan kehidupan keluarga, sehingga kaum perempuan secara umum hanya mengekor kaum lelaki. ${ }^{17}$ Secara singkat dapat dikatakan bahwa posisi perempuan pada masa pra Islam sebagai berikut : 1) Dari sisi kemanusiaan, perempuan tidak memiliki tempat terhormat pada laki-laki karena tidak adanya pengakuan atau sifat laki-laki terhadap peran perempuan dalam mengatur masyarakat. 2) Ketidak setaraan terhadap anak laki-laki dan perempuan, suami dan istri dalam lingkungan keluarga. 3) Mengesampingkan kepribadian atau kompetensi perempuan dalam memperoleh kehidupan, sehingga perempuan tidak memiliki hak dalam persoalan waris dan kepemilikan harta. Dari uraian di atas dapat disimpulkan bahwa mereka tidak ada sikap "memanusiakan" perempuan, baik di sebabkan oleh pengingkaran kemanusiaannya atau karena ada anggapan dari kaum laki-laki bahwa peran perempuan tidak dapat diandalkan dalam berbagai sektor kehidupan di masyarakat.

\section{Penanaman Nilai-Nilai Pendidikan Islam Terhadap Anak}

Penanaman nilai-nilai pendidikan Islam terhadap anak merupakan tanggung jawab bersama antara ayah dan ibu sebab pendidikan yang pertama dan utama diperoleh anak adalah dalam keluarga. Keluarga mempuanyai peran yang sangat penting dalam pendidikan anak, khususnya dalam penanaman nilai-nilai pendidikan Islam sebagai pondasi awal dalam menjalani kehidupan, karena anak

\footnotetext{
${ }^{16}$ Ibid, 5.

${ }^{17}$ Ibid, 37.
} 
terlahir dengan segala potensi yang dimiliki dan tergantung orang tuanya yang dapat membantu dan mengarahkan segala potensi kebaikan pada anak. Oleh karena itu, penanaman nilai-nilai pendidikan Islam sejak dini merupakan pendidikan yang sangat penting karena pada fase inilah seorang pendidik bisa menanamkan prinsip-prinsip yang lurus dan orientasi yang baik dalam jiwa dan perilaku anak. Mendidik dan mengajar anak bukan perkara yang mudah dan bukan pekerjaan yang bisa dilakukan sambil lalu karena mendidik dan mengajar anak pada dasarnya kewajiban orang tua terutama ibu yang tidak dapat digantikan sepenuhnya oleh orang lain. Mendidik anak adalah suatu keharusan yang telah digariskan oleh Allah Swt.

Tanggung jawab orang tua terutama ibu dalam menanamkan nilai-nilai pendidikan Islam terhadap anak yang paling utama menurut Abdullah Nashih 'Ulwan adalah sebagai berikut:

\section{Pendidikan Iman}

Maksud dari pendidikan iman di sini adalah mengikat anak dengan dasardasar keimanan, rukun Islam, dan dasar-dasar syariat semenjak pertumbuhannya dimana anak sudah mulai mengerti dan memahami sesuatu sehingga anak akan terikat dengan agama Islam secara akidah dan ibadah. Yang dimaksud dengan dasar-dasar keimana adalah segala sesuatu yang ditetapkan oleh Allah Swt tentang hakikat keimanan, perkara-perkara gaib, seperti iman kepada Allah, malaikat, kitab-kitab samawiyah, semua rasul, pertanyaan dua malaikat (di alam kubur), azab kubur, kebangkitan, hisab (pengadilan), surga, neraka, dan semua perkara gaib. Sedangkan yang dimaksud dengan rukun Islam adalah semua peribadatan anggota dan harta, seperti shalat, puasa, zakat, haji bagi yang mampu melaksanakannya. Adapun yang dimaksud dengan dasar-dasar syariat adalah setiap perkara yang bisa mengantarkan kepada manhaj rabbani (jalan Allah), ajaran-ajaran Islam baik akidah, ibadah, akhlak, hukum, aturan-aturan, dan ketetapan-ketetapan. ${ }^{18}$

${ }^{18}$ Abdullah Nashih 'Ulwan, Tarbiyatul 'Aulad Fil Islam, terj. Arif Rahman Hakim, Pendidikan Anak Dalam Islam (Cet. III; Sukoharjo: Insan Kamil, 2013), 111. 
Adapun beberapa petunjuk mengenai pendidikan iman sebagaimana yang telah diwasiatkan oleh Rasulullah Saw meliputi:

a. Membuka kehidupan anak dengan kalimat Tauhid La ilaha illallah,

b. Mengajarkannya masalah halal dan haram setelah ia berakal,

c. Memerintahkannya untuk beribadah saat umurnya tujuh tahun,

d. Mendidiknya untuk cinta kepada Nabi, keluarga-Nya, dan cinta membaca Al-Qur'an. ${ }^{19}$

\section{Pendidikan Moral}

Maksud pendidikan moral adalah kumpulan dasar-dasar pendidikan moral serta keutamaan sikap dan watak yang wajib dimiliki oleh seorang anak dan menjadi kebiasaan anak semenjak usia tamyiz hingga ia menjadi mukallaf (balig) dan terus berlanjut secara bertahap hingga dewasa sehingga di dalam dirinya sudah tertanam prinsip-prinsip akhlak dan nilai-nilai moral yang merupakan buah dari iman yang tertanam kokoh, dan pertumbuhan agama yang benar. ${ }^{20}$

Adapun dasar-dasar pendidikan moral bagi anak yang telah diajarkan Rasulullah Saw meliputi: ${ }^{21}$

a. Menghindarkan anak dari perilaku ikut-ikutan (taqlid buta),

b. Mencegahnya agar tidak tenggelam dalam kesenangan yang mengakibatkan kelalaian dan tergelincir ke dalam kesesatan dan penyimpangan,

c. Melarangnya mendengar musik dan nyanyian porno,

d. Melarangnya bergaya dan berlagak seperti wanita,

e. Melarangnya membuka aurat, tabarruj, ikhtilath, dan melihat hal-hal yang diharamkan.

Setelah dijelaskan mengenai dasar-dasar pendidikan moral dalam pendidikan anak, maka diharapkan anak memiliki perilaku-perilaku akhlak yang mulia dan menjauhi perilaku-perilaku akhlak yang tercela. ${ }^{22}$

${ }^{19}$ Ibid, 127.

${ }^{20}$ ibid, 131.

${ }^{21}$ ibid, 143. 2008) 16 .

${ }^{22}$ Heri Jauhari Muchtar, Fiqih Pendidikan, (Bandung: PT Remaja Rosdakarya Offset, 
Rustina, Analisis Peran ... | 221

\section{Pendidikan Fisik}

Pendidikan yang dipikul Islam diatas pundak para pendidik atau orang tua diantaranya adalah pendidikan fisik yang dimaksudkan agar anak bisa tumbuh dan dewasa dengan memiliki sifat yang kuat, sehat, dan bersemangat.

Pendidikan fisik yang yang digariskan dalam Islam diantaranya adalah sebagai berikut. ${ }^{23}$

a. Kewajiban memberikan nafkah kepada keluarga dan anak,

b. Mengikuti aturan-aturan kesehatan dalam makan dan minum,

c. Membentengi diri dari penyakit menular,

d. Mengobati penyakit,

e. Menerapkan prinsip tidak boleh membahayakan diri sendiri dan orang lain,

f. Membiasakan anak gemar berolahraga dan manaiki tunggangan,

g. Membiasakan anak untuk zuhud dan tidak larut dalam kenikmatan,

h. Menanamkan karakter bersungguh-sungguh dan perwira kepada anak.

4. Pendidikan Akal

Pendidikan akal adalah pembentukan pola pikir anak dengan hal-hal yang bermanfaat, seperti ilmu syar'i, kebudayaan, ilmu modern, kesadaran, pemikiran, dan peradaban sehingga anak menjadi matang secara pemikiran dan terbentuk secara ilmu dan kebudayaan. Pendidikan akal ini merupakan penyadaran, pembudayaan, dan pengajaran. ${ }^{24}$ Jadi pendidikan akal itu tertuju pada akal dan otak manusia agar semakin berkembang tentang ilmu-ilmu pengetahuan.

Tanggung jawab pendidik dalam pendidikan akal terhadap anak ada beberapa tahapan yang harus dijalankan, yaitu kewajiban mengajar, kesadaran pemikiran, dan kesehatan akal. ${ }^{25}$

\footnotetext{
${ }^{23}$ 'Ulwan, Tarbiyatul 'Aulad, 163.

${ }^{24}$ Ibid, 199.

${ }^{25}$ Ibid, 200.
} 


\section{Pendidikan Kejiwaan}

Maksud pendidikan kejiwaan adalah mendidik anak agar berani dan terus terang, mandiri, suka menolong, dapat mengendalikan emosi, dan menghiasi diri dengan segala bentuk kemuliaan akhlak. Tujuan pendidikan ini adalah membentuk, menyempurnakan, serta menyeimbangkan kepribadian anak sehingga ketika sudah dewasa, ia mampu melaksanakan kewajibannya dengan sempurna. ${ }^{26}$

Adapun penulis akan menjelaskan beberapa faktor yang dapat menghancurkan eksistensi kepribadian anak sekaligus cara mengatasinya menurut kaidah Islam, yaitu sebagai berikut.

a. Minder atau kurang percaya diri merupakan tabiat buruk bagi anak, adapun cara menaggulangi masalah ini adalah membiasakan anak untuk bergaul dengan orang lain, hal ini dapat membantu anak lebih percaya diri serta mendorong anak untuk bersosialisasi dan tidak takut akan celaan.

b. Takut merupakan situasi kejiwaan yang dapat menghinggapi siapa saja, baik anak kecil maupun dewasa, laki-laki atau perempun. Sikap ini merupakan hal yang wajar selama masih sesuai dengan batasan-batasan tabiatnya. Adapun solusi dari masalah ini yaitu dengan cara menumbuhkan keimanan kepada Allah swt dalam diri anak sejak dini, membiasakan anak agar bisa bertanggung jawab atas setiap tindakannya, memberikan kesempatan bergaul kepada anak, dan mengajarkan kepada anak jejak Rasulullah Saw dan para pengikutnya agar cinta kepada jihad.

c. Perasaan memiliki kekurangan merupakan keadaan kejiwaan yang mengkhawatirkan karena bisa membawa anak kepada kehidupan yang hina, sengsara dan penuh dosa. Adapun solusi dalam mengatasi gejala ini yaitu bertahap dalam mendidik anak dengan mengarahkan dan menasihati agar anak termotivasi sehingga rasa minder dalam diri mereka perlahanlahan hilang.

d. Hasad merupakan keinginan agar nikmat hilang dari orang lain dan membawa pengaruh buruk bagi anak. Solusi untuk mengatasi masalah ini

${ }^{26}$ Ibid, 239. 
yaitu mencurahkan cinta kasih kepada anak, mewujudkan keadilan di antara sesama anak, dan menghilangkan faktor-faktor yang menyebabkan hasad. $^{27}$

\section{Pendidikan Sosial}

Pendidikan sosial adalah mengajari anak sejak dini agar berpegang pada etika sosial dan dasar-dasar kejiwaan yang bersumber dari akidah Islam, tujuannya agar anak mampu berinteraksi sosial dengan baik dan beradab. Dalam pendidikan sosial, anak akan diperkenalkan mengenai hal-hal yang terdapat atau terjadi di masyarakat serta cara hidup di masyarakat, juga pendidikan etika dalam masyarkat ${ }^{28}$. Dengan adanya pendidikan ini diharapkan anak memiliki wawasan kemasyarakatan dan mereka dapat hidup serta berperan aktif di masyarakat secara benar. $^{29}$

\section{Pendidikan Seks}

Pendidikan seks adalah suatu upaya pengajaran, penyadaran, dan penerangan kepada anak ketika ia sudah memahami hal-hal yang berkenaan dengan naluri seks dan pernikahan.

Adapun pendidikan seks yang harus diperhatikan oleh para pendidik memiliki beberapa fase, yaitu sebagai berikut.

a. Fase pertama, usia antara 7-10 tahun, disebut masa tamyiz (masa kanakkanak usia akhir). Pada masa ini, anak-anak diajarkan etika meminta izin masuk (ke kamar orang tua dan orang lain) dan etika melihat (lawan jenis).

b. Fase kedua, usia antara 10-14 tahun, disebut usia remaja. Pada masa ini anak dijauhkan dari segala hal yang mengarah kepada seks.

c. Fase ketiga, usia antara 14-16 tahun, disebut usia balig. Pada masa ini anak diajarkan tentang etika berhubungan badan, ketika ia sudah siap untuk menikah.

${ }^{27}$ Ibid, 239-279.

${ }^{28}$ Miftahul Huda, Interaksi Pendidikan 10 Cara Qur'an Mendidik Anak, (Malang: UIN Malang Press,2008), 298.

${ }^{29}$ Muchtar, fikih pendidikan, 16. 
d. Fase keempat, usia setelah balig yang disebut dengan usia pemuda/pemudi. Pada masa ini anak diajarkan tentang cara-cara menjaga kehormatan dan menahan diri ketika ia belum mampu untuk menikah. ${ }^{30}$

\section{PENUTUP}

1. Bentuk penanaman nilai-nilai pendidikan Islam terhadap anak dalam keluarga yakni perempuan memiliki peranan yang sangat penting dalam hal pendidikan, bahkan pendidikan pertama yang diberikan kepada anak ialah dari seorang ibu. Ibu memiliki andil yang besar dalam melakukan pengembangan potensi anak .sehingga Ada sebuah pepatah yang mengatakan jika perempuan cerdas akan melahirkan anak-anak yang cerdas pula.

2. Faktor pendukung perempuan berperan ganda dalam menanamkan nilai-nilai pendidikan Islam terhadap anak adalah Semangat untuk berpendidikan makin lama kian pudar seiring dengan hambatan-hambatan yang terjadi. Jikalau menikah dibarengi dengan studi, maka perempuan akan mengalami peran ganda dan mengharuskan perempuan untuk bekerja keras untuk melakukan penyeimbangan, dalam konteks sosial yang masih berlutut pada pemikiran gender konvensional. Seperti pemikiran yang mengungkapkan bahwa suatu hal yang wajar jika laki-laki bekerja atau memperoleh segala impiannya, baik melakukan pengembangan diri ataupun melanjutkan studi, bukan mengurusi perkara domestik. Sehingga kondisi lain mengatakan masih banyaknya pelecehan terhadap perempuan pada dunia pendidikan.

30‘Ulwan, Tarbiyatul 'Aulad, 423. 
Rustina, Analisis Peran ... | 225

\section{DAFTAR PUSTAKA}

Afgand, Iis Nuraeni dan Novi Hidayati Afsari, Ternyata Wanita Bukan Makhluk Lemah, Bandung: Ruang Kata, 2011.

Amir, Sayyid, Ali. Api Islam, (Terjemahan HB Yasin). Jakarta: PT. Pembangunan, 1967.

Asghar, Ali, Engineer. Hak-Hak Perempuan Dalam Islam, Terj. Farid Wajidi dan Cicik Farkha., Yogyakarta: LSPPA, 2000.

Chalil, Moenawar Chalil, Nilai Wanita, Solo: Ramadhani, 1984.

Ch, Mufidah, Psikologi Kelurga Islam Berwawasan Gender, Malang: UIN Malang Press, 2008.

Daulay, Haidar Putra, Pendidikan Islam dalam Perspektif Filsafat, Cet. I; Jakarta: Kencana, 2014.

Fakih Mansur. Analisis Gender dan Transformasi Sosial, Cet. IX .Yogyakarta: Pustaka Pelajar, 2005.

Hidayah Nurul, "Peran Wanita Karir Dalam Pendidikan Islam Di Dusun Mongkrong, Karangjati, wonosegoro, Boyolali”, http://eprints.iainsurakarta.ac.id/1539/ (28 Oktober 2020).

Huda, Miftahul Huda, Interaksi Pendidikan 10 Cara Qur'an Mendidik Anak, Malang: UIN Malang Press, 2008.

Hasyim Syafiq. Pengantar Feminisme dan Fundamentalisme Islam, Cet. I. Yogyakarta: LkiS, 2005.

Jacqueline, Chabaud, Mendidik Dan Memajukan Wanita., Jakarta: Gunung Agung Depag RI. 2005.

MuslikhatiSit, Muslikhati, Feminisme dan Pemberdayaan Perempuan dalam Timbangan Islam Jakarta: Gema Insani Press, 2004.

Muchtar, Heri Jauhar, Fiqih Pendidikan, Bandung: PT Remaja Rosdakarya Offset, 2008. 
226 | MUSA WA, Vol. 13 No.2 Desember 2021 : 203-226

Nashih Abdullah Nashih 'Ulwan, Tarbiyatul 'Aulad Fil Islam, terj. Arif Rahman Hakim, Pendidikan Anak Dalam Islam, Cet. III; Sukoharjo: Insan Kamil, 2013.

Wahid Umaimah dan Ferrari Lancia,"Pertukaran Peran Domestik dan Publik Menurut Perspektif Wacana Sosial Halliday", https://doi.org/10.29313/mediator.v11i1.3180 (28 September 2021). 